\title{
BIOGRAPHY OF PROFESSOR EBER LANDAU AND HIS CONTRIBUTION TO ANTHROPOLOGY, ANATOMY AND NEUROLOGY AT THE UNIVERSITIES IN ESTONIA, LITHUANIA, AND SWITZERLAND
}

\author{
Aleksandras Vitkus ${ }^{1}$, Andres Arend ${ }^{2}$, Margus Puusepp ${ }^{2}$, \\ Marina AunapuU ${ }^{2}$, Vytautas Siudikas ${ }^{3}$ \\ ${ }^{1}$ Department of Histology and Embryology, Lithuanian University of Health \\ Sciences, Lithuania \\ ${ }^{2}$ Department of Anatomy, University of Tartu, Estonia \\ ${ }^{3}$ Department of Social Medicine, Lithuanian University of Health Sciences, \\ Lithuania
}

\begin{abstract}
This article provides an overview of the scientific activities of Professor Eber Landau (1878-1959) in Estonia, Lithuania, France, and Switzerland. In addition to providing chronological data about the academic life of Prof. Landau, in particular at the Universities of Tartu, Bern, Kaunas, and Lausanne, the article emphasizes his contribution to the development of anatomy, anthropology, histological techniques, neurohistology, and neurology. In the latter two fields, the eponyms Landau reflex, or radiopronator superius reflex, and synarmotic cells of Landau, a subtype of non-traditional large neurons in the granular layer of the cerebellar cortex, have engraved his name in medical history.
\end{abstract}

Keywords: Eber Landau; history of medicine; Landau reflex; synarmotic cells of Landau

\section{INTRODUCTION}

In essence, science is international and stands above nations, countries, and languages of scientific communication. The academic life of Professor Eber Landau, who worked at different universities in several countries and wrote 
research papers in many languages, is a good example of the universal and cosmopolitan nature of science. Publications by Landau appeared in French, German, English, Russian, Lithuanian, Italian, Polish, and Latvian. We know Landau first of all as a neurohistologist, who contributed much to improve histological techniques, but also as an anatomist and anthropologist. Besides, he worked as a neurologist who described the radiopronator superius reflex, which we now know as Landau's reflex.

Eber Landau (Abraam Eber Girshovitch Landau) was born on 26 October 1878 (Figure 1) [4] in Rezhitze (today, Rezekne in Latvia). In his curriculum vitae (Figure 2) [2] Landau emphasised that "by my place of birth I am a Latvian". In his identity documents was also written: nationality - Latvian, citizen of Latvia. Landau writes: "I come of an old Jewish family, which was already known for its kindheartedness even in the $14^{\text {th }}$ century in Pfalz, Bavaria. My surname is derived from the name of a local town, Landau, which is in Kurpfalz, Bavaria". This statement has been confirmed through investigations by Prof. Nadeis, manager of Landau Town Museum [2, 14,16].

Landau's parents were merchants who had four children, of whom Eber was the eldest. At first he was educated in Rezekne, later attending a classical gymnasium in Riga, capital of Latvia. His parents wanted him to continue their profession, but their efforts failed because Eber had no interest in business. Instead, he was fond of observing nature and artistic works.

Upon graduating from the classical secondary school in Riga, Eber Landau succumbed to the innate practicality of his family and decided to take up a course of medical studies at the Medical Faculty of Dorpat University, in those days officially called Imperial Yuryev University and known today as the University of Tartu (Figure 3). Upon finishing his course of medical studies in 1902, he received a physician's diploma, allowing him to practice medicine. While a student, Landau wrote an interesting research work on "Moral and Political Views of Euripides". For this work he was awarded a silver medal by the University.

E. Landau improved his qualifications by working at the Villefranche-surMer Zoological Station where he investigated the nervous system of Ctenophora and studied artificial insemination of sea urchins. In 1903, Landau attended a course at the histology laboratory in Munich and in 1903-1904 he worked as an assistant at the Institute of Anatomy under the guidance of Prof. P. Leshaft in St. Petersburg. 

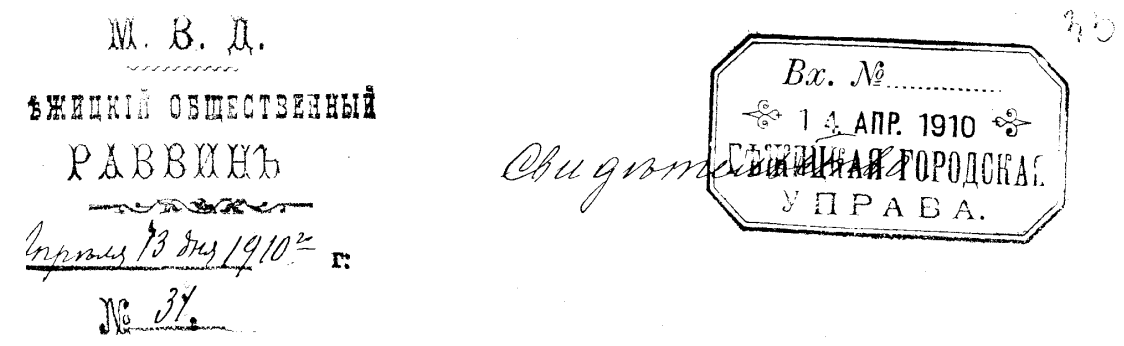

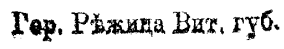

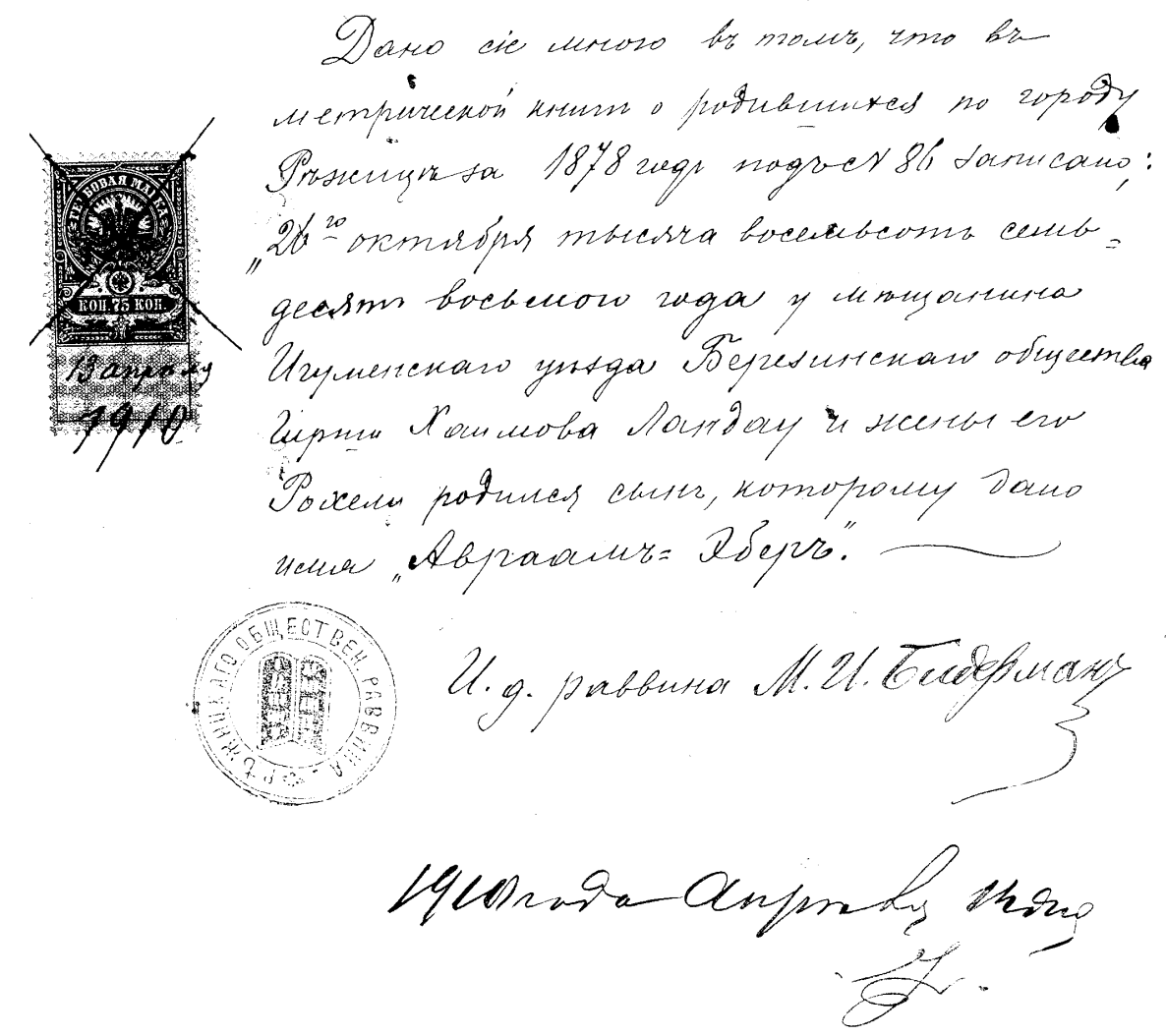

Figure 1. Certificate of Birth of Abraam Eber Landau [4]. 
Prof. Dr. E. Landau

BERNE

Jungtrangtraese 18

$$
\text { Euresculum vilar }
$$

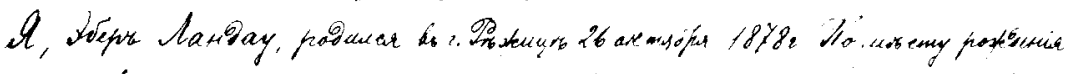

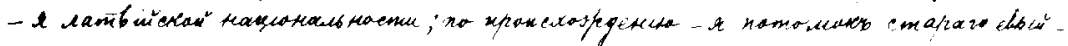

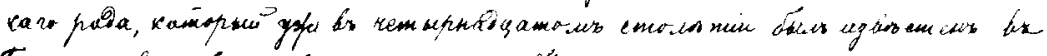

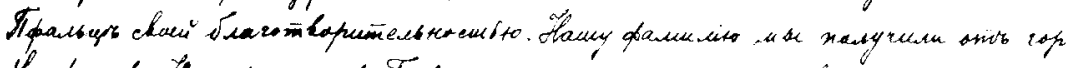

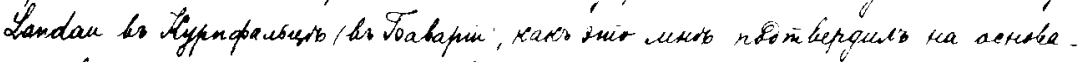

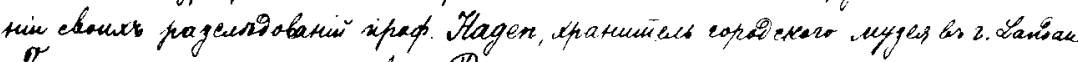

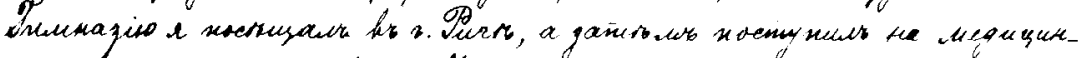

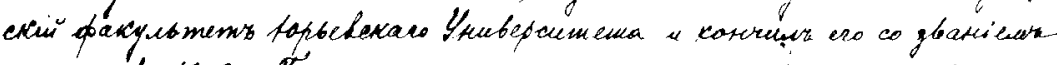

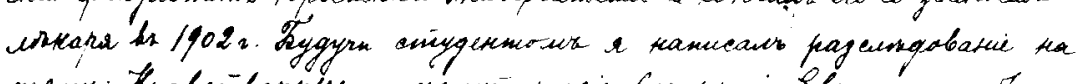

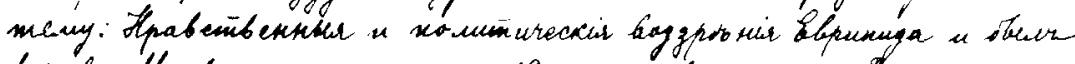

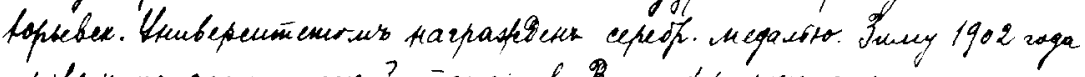

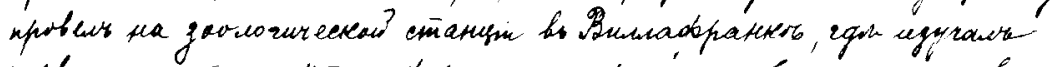

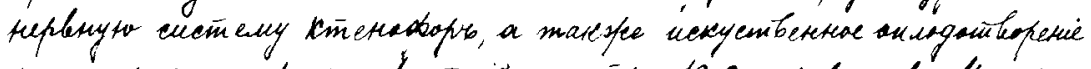

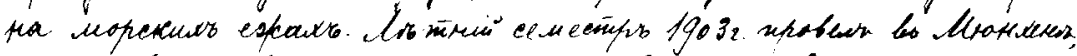

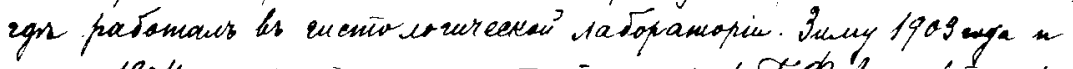

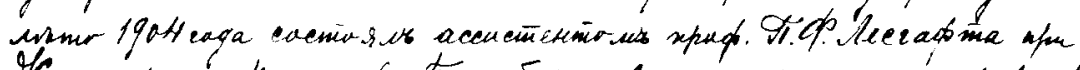

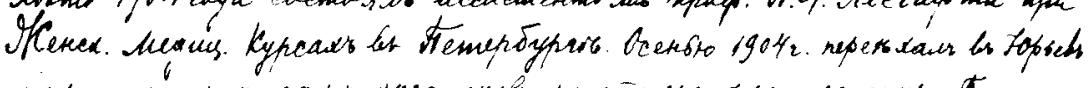

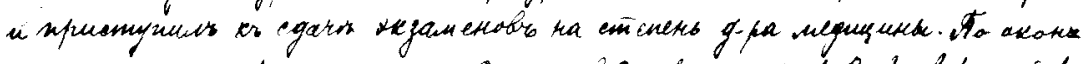

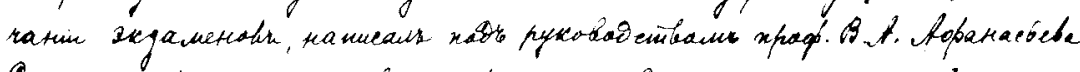

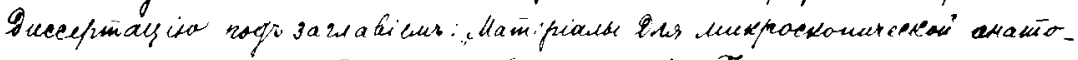

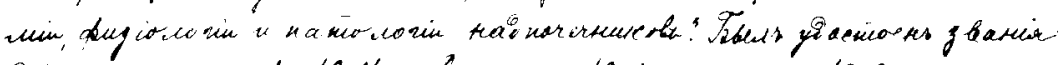

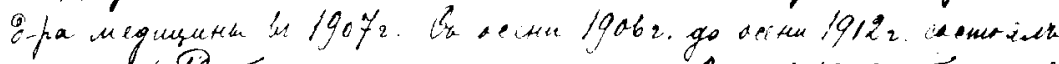

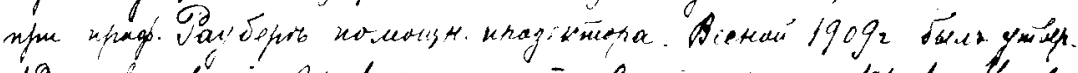

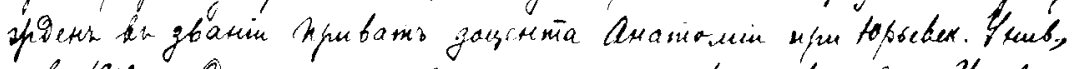

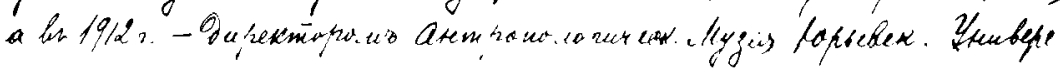

Figure 2. Curriculum vitae of Eber Landau [2]. 


\section{ESTONIA. DORPAT UNIVERSITY}

In the autumn of 1904, Eber Landau returned to Dorpat University and completed his doctoral thesis on microscopic anatomy, physiology, and pathology of the adrenals under the guidance of Prof. V.A. Afanasjev [2, 7].

In 1906-1912, Landau worked as a prosector's assistant at the Institute of Anatomy headed by the famous professor A. Rauber [3, 5] whom Landau mentioned as his tutor and long-standing mentor. Under Rauber's guidance and influence, Landau matured as a young scientist and educator, acquiring extensive knowledge and improving his practical skills both in teaching and research methodology.

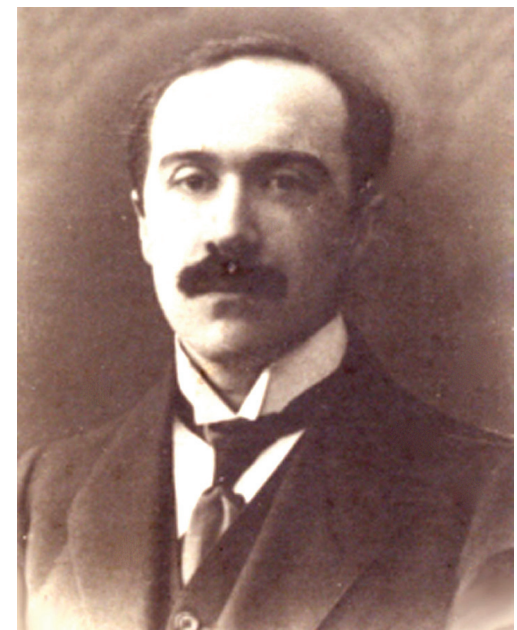

Figure 3. Eber Landau in 1908, picture from the collection of portraits of the teaching staff of the medical faculty of Imperial Yuryev University (Dorpat University).

Upon passing his examinations in May 1907, Landau defended his doctoral thesis and was awarded the degree of Doctor of Medicine in February 1908 (Figure 3) [13]. In 1909, Landau was elected as an associate professor at Dorpat (Yuryev) University. In 1910, he made a proposal to the leading authorities of Dorpat University to use his collection of anthropological samples for demonstration purposes during lectures on anthropology [6]. This activity gave him an impetus to establish a museum of anthropology, and in 1912 he was appointed as director of the Anthropology Museum of Dorpat University $[1,6]$.

\section{SWITZERLAND. BERN UNIVERSITY}

On 12 January 1913, Landau left Dorpat University to become an associate professor at the University of Bern (Figure 4). Two years later, in 1915, he was appointed as Professor Extraordinary of Anatomy and Somatic Anthropology at the University of Bern. In 1920 he became editor of "Revue de Biologie Sociale", the journal of the University's Department of Man and Nature [14, 16].

During the First World War (1915-1918), Landau worked as a military physician. As a citizen of Russia (because both Latvia and Estonia at that time were under the rule of Russia), he was conscripted into the Russian Army by the Russian Embassy in Bern and sent to France, where he was appointed to 
Itu die Situicele Vertretung

$$
\text { in Kannas. }
$$

Tehr vechter Herr.

An 2.eptender 1897 wurde coh auf die medizimirehe Fakult it der Universit it Iarte aufgenonmen Im ${ }^{4}$ ahe 1902 abolvierte in als Aryt bi medizi. nische Faxult at der Universit tät; a m 29 stai 1907 wurde ich zum Doctar meticinae fromoviert. Tom 1 September 1906 war ch Prosektorgehile am Anatouischen Institut (Dir. Brof. S. Rauber) uno vom 30 Tamuar 1909- Rivatdorent fiir Anatovic in Frikling 1913 roy coh nach Bern. Alle meine Lokumente sind in Sartu geblicben. Sort nuissu alle Soxkmente sein, welche cich eivelichte beim Sin. treteu in die Universität, dort ist auch mein Aer, diplom, anch meiu tor ned-biplon geblieden. Dirfte ich Sie bitten, bei der Hodschule anyu. bragen, ob es nicht nionglich waire, mir hierher meine dothmente zu ribersenden.

Adr: Maunas,

$$
\begin{aligned}
& \text { thit voryuglicher Hochachtung } \\
& \text { Luksio g-ve 12. butu } 6 \text {. }
\end{aligned}
$$$$
\text { Tel. } 267
$$

Figure 4. Landau confirms the fact that he received documents necessary to leave for Bern University in 1913. 
serve in a military hospital. He worked there as a neurologist at the Hôpital de la Salpêtrière in Paris for 18 months. The clinic was headed by Professor J. Déjerine [1]. While working there, Landau acquired extensive data and collected copious neurological records (over 8000 cases) for his future research work. In collaboration with Prof. J. Déjerine and his wife, Landau wrote a comprehensive article about the connections in the development of the skull and the brain. In 1917, he discovered a new type of reflexes in the upper extremities, the so-called radiopronator superius reflex, or the Landau reflex [1].

After the death of Prof. J. Déjerine, Landau moved to the Val-de-Grace military hospital, where he worked in the Psychiatric Department headed by Doctor Brian. Some time later, Landau was appointed as an assistant to the Chief of the First Sanitary Department of the Russian Army in France. During the final period of his military service in the Russian Army, he was appointed Chief of the Second Evacuation Commission.

During the war, Landau had a good opportunity to improve his qualifications not only in Paris, but also in Munich, where he also stayed for a short time with Prof. S. Mollier and Dr. A. Bohm, and in Zurich at the Institute of Anthropology where he worked together with Prof. R. Martin and Prof. C.v. Monakow. He also visited some other universities in Western Europe [1].

In 1918, at his own request, he was dismissed from the service in the Army and returned to the University of Bern in Switzerland $[3,16]$. On return to the University of Bern, Landau worked as professor extraordinary at the Institute of Anatomy, headed by Prof. H. Strasser.

Switzerland, particularly Bern, became his new home, and he obtained Swiss citizenship. His scientific activity and ample relations with scientists of other countries greatly expanded. Landau was elected as a corresponding member of the Medico-Psychological Society of Paris, and a Member of the Society of Anthropology in Rome [2, 15].

\section{LITHUANIA. KAUNAS UNIVERSITY}

In May 1923, Landau was invited to Kaunas to assume the position of professor and chief of the Department of Histology and Embryology of the University of Lithuania. On receiving his consent, the Board of the Medical Faculty elected Landau head of the Department of Histology in October 1923. At the age of 45, in the prime of life, Professor Eber Landau arrived in Kaunas on 28 November 1923 and took up his duties as a head of the Department of Histology and Embryology on 1 December 1923 [12] (Figure 5). 
All organizational responsibilities of establishing a new Department fell upon Landau's shoulders. He had only one person to help him. At the beginning, the Department of Histology and Embryology had only one room in the building of the Faculty of Medicine. Under Landau's guidance, the personnel of the Department of Histology increased (Figure 6), and the Department acquired new histological instruments and devices, such as microscopes, microtomes, and thermostats. A special photolaboratory was also set up. At the same time,

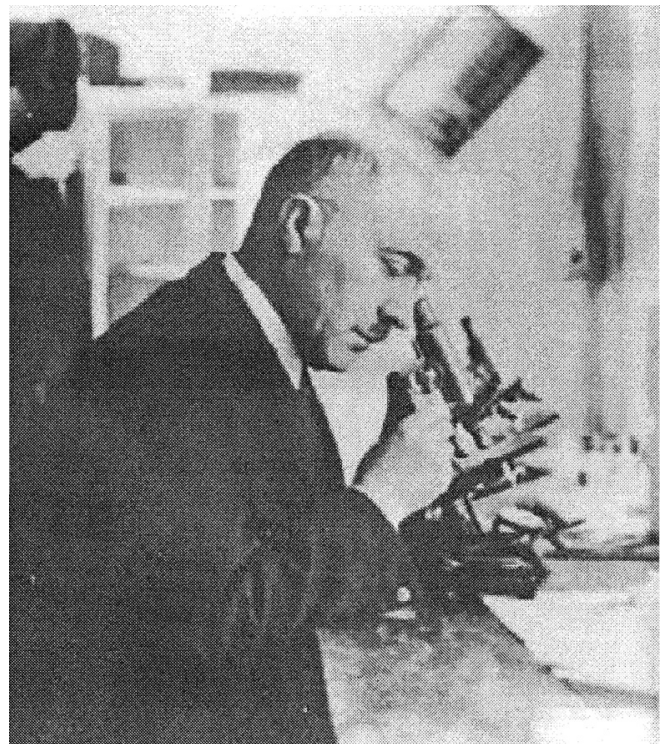

Figure 5. Prof. Eber Landau at the Department of Histology and Embryology of the University of Lithuania.

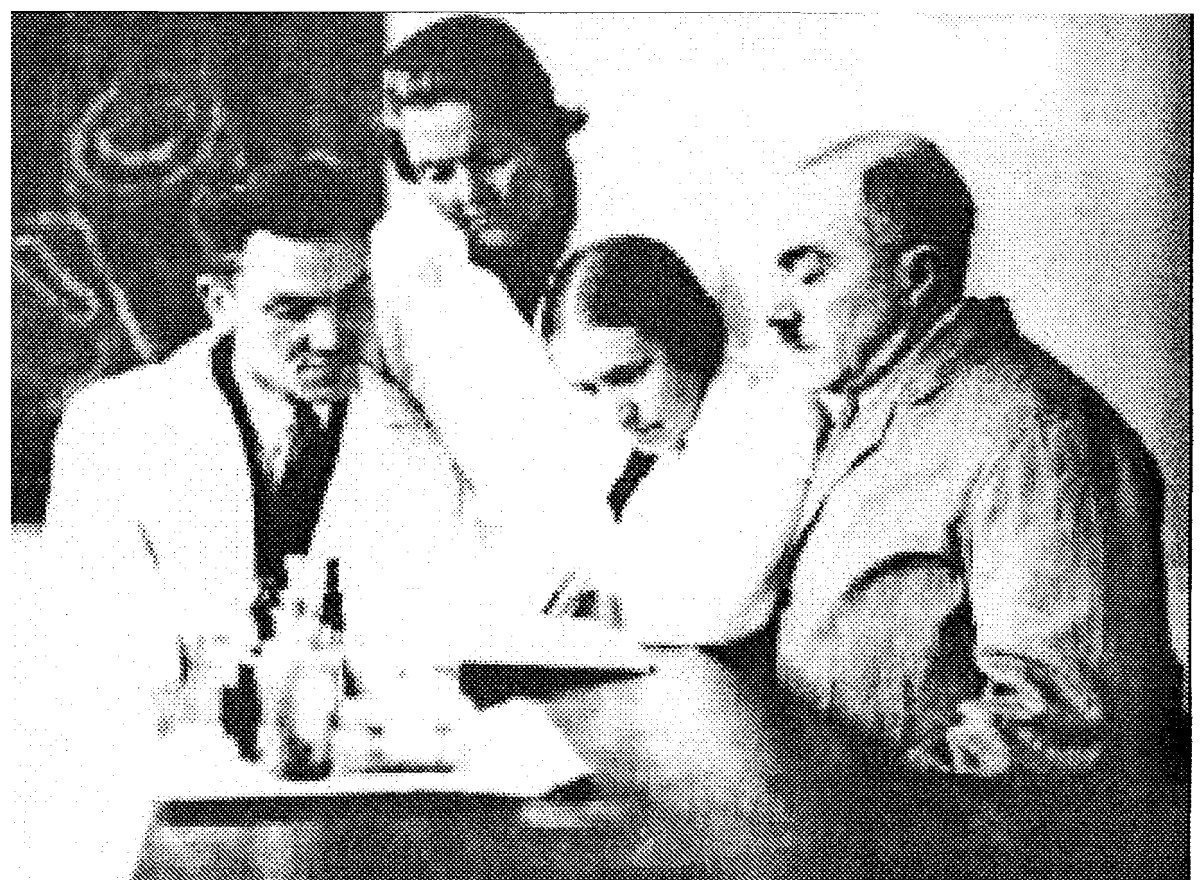

Figure 6. Prof. Landau with research fellows at the Department of Histology and Embryology of the University of Lithuania. 
Landau was elected a member of the Board of the Faculty of Medicine. Soon he developed a new project for constructing a larger and more convenient layout of the Department. Realization of the plan started only in 1931, just before he left Lithuania for Switzerland.

Landau was also a prominent scientist. During his working period of over eight years in Kaunas, he wrote scientific articles mainly on neurohistology and histological techniques. At that time, he was particularly interested in anatomical structure of the cerebellum. He also discovered a new type of cells in the granular layer of the cerebellar cortex, designated the synarmotic cells [11], which are nowadays grouped as a subtype of non-traditional large neurons. Landau was always searching for new ways of fixation and staining. In his attempts to stain the cellular nucleus, he produced a dyeing substance derived from the seeds of sunflowers growing in his garden and called it "Saulezolin" by the name of the plant in Lithuanian [9]. He invented new ways of fixing, staining, and impregnating histological tissues, and wrote the very first manual on histological techniques in the Lithuanian language [10].

Landau gained wide-ranging experience by working in many medical schools in various modern universities in Europe. His methodological experience was readily used by the teaching personnel of other departments who were interested in histological techniques. For example, Austra Bebis, a laboratory assistant from Riga University, created a new method for staining muscle tissues when attending qualification courses at the Department of Histology in Kaunas.

Between 1925-1929, Landau carried out ideological seminars and discussions with proponents of Darwinism (professors P. Avizhonis, V. Lashas, T. Ivanauskas, Dr. J. Shliupas et al.), defending his theory of vitalistic biological relativity propagated in his lectures and articles [8]. Landau also delivered public lectures on medical and biological questions.

\section{SWITZERLAND. LAUSANNE UNIVERSITY}

On 21 April 1932, Landau left Kaunas with his family [15] (Figure 7). He arrived in Lausanne as a highly qualified specialist and well-known scientist. With all his vigour and energy, he plunged into research and educational activities at the University of Lausanne. In Lausanne, Landau continued his research on the morphology of the cerebellum initiated at Kaunas University. Later he shifted his attention to the study of other neurohistology topics: he investigated the autonomic nervous system, peripheral nerves, cytoarchitectonics and myeloarchitectonics of different areas in the brain and at the same time continued investigating histological techniques. He was also interested in other areas such 


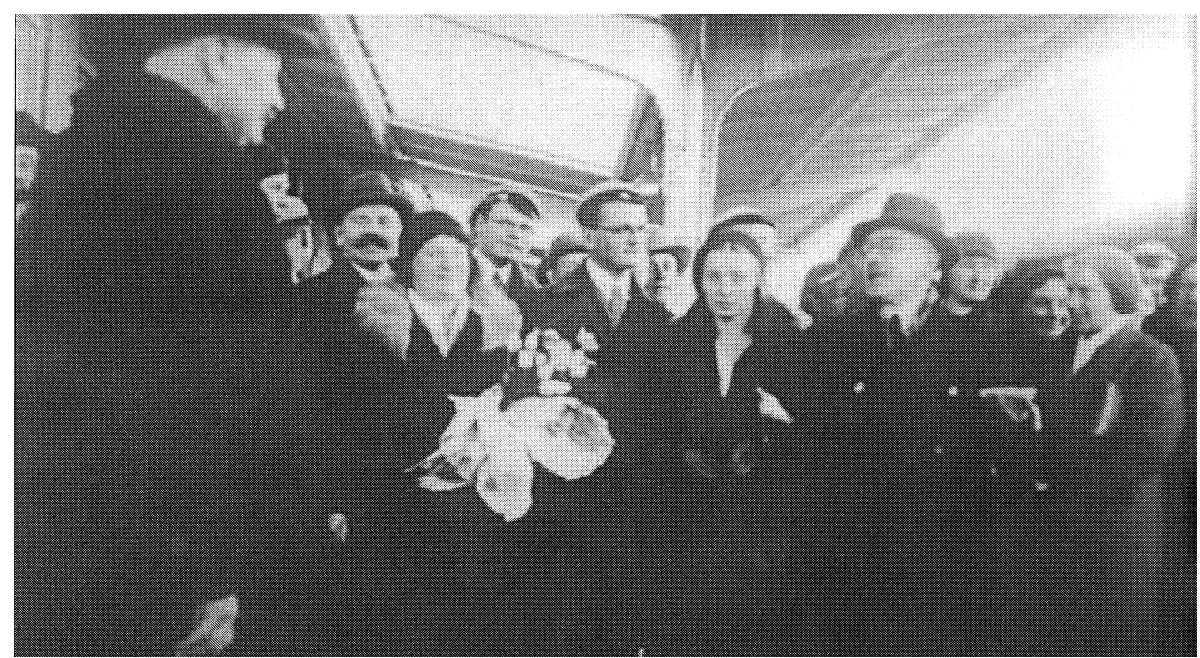

Figure 7. Teaching staff and students of the University of Lithuania came to see Prof. Landau off leaving for Lausanne in 1932.

as histology of the parathyroid gland and the alimentary tract as well as investigating brain anatomy. He was academic supervisor of twelve dissertations, also attending scientific conferences and international congresses. As his health deteriorated in 1950, Professor Landau resigned from duties at the University of Lausanne, staying there as an honorary professor of neurohistology till the very last day of work [1].

Eber Landau died of a heart attack on 30 October 1959. He left behind him an ample scientific heritage: 173 publications and 12 doctoral dissertations completed under his guidance. Although most of his publications were in French and German, a number of articles were also written in English, Russian, Lithuanian, Italian, Polish, and Latvian.

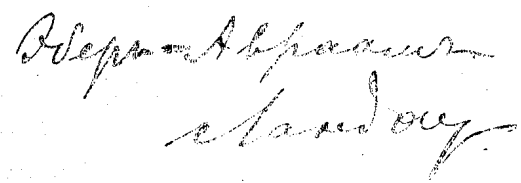

Signature from passport.

\section{REFERENCES}

1. Bucher O. (1960). Eber Landau. Ein Nachruf. Anatomischer Anzeiger 108, 208-220.

2. Central State Archives of Lithuania. F.631. Ap.3. V. 374. 
3. Estonian History Archives, Stock 402, Series 3, Item 928, 2-2p.

4. Estonian History Archives, Stock 402, Series 3, Item 928, 33.

5. Estonian History Archives, Stock 402, Series 3, Item 928, 54p.

6. Kasmel J. (2001). About the establishment of the anthropological collection of Yuryev (Tartu) University in 1911. Papers on Anthropology 10, 117-122.

7. Landau E. (1907). Microscopical anatomy, physiology, and pathology of suprarenal glands. Doctoral dissertation, Yuryev University (Tartu). [In Russsian.]

8. Landau E. (1925). Biologiškoji reliatyvybès teorija [Theory of Relativity in Biology]. Kosmos 5, 265-375. [In Lithuanian.]

9. Landau E. (1930a). Saulèžolin - nauji dažai histologijos technikoje [Sunflower as a source of a new type of dyes used in histology]. Medicina (Kaunas) 1, 30-1. [In Lithuanian.]

10. Landau E. (1930b). Trumpas histologijos technikos vadovèlis [A short manual of histological techniques]. Kaunas. [In Lithuanian.]

11. Landau E. (1933). La cellule synarmotique dans le cervelet humain. Arch Anat 17, 273-285.

12. Mažylis P. (1924). Lietuvos universiteto Medicinos fakulteto 1923-1924 mokslo metu apyskaita [The account of the academic year 1923-24 of the Medical Faculty of Lithuanian University]. Medicina (Kaunas) 6-7, 512-519. [In Lithuanian.]

13. Scientific articles of Yuryev University. Particular accounts, 1910. Yuryev (Dorpat) p. 1-25. [In Russian.]

14. Valančiūtė A., Baltrušaitis K., Vitkus Albertas, Vitkus Aleksandras (2003). Kauno medicinos universiteto histologijos ir embriologijos katedrai - 80 metu [80 years of the Department of histology and embryology of Kaunas Medicine University]. Medicina (Kaunas) 39, 915-918. [In Lithuanian.]

15. Vitkus A., Siudikas V. (2003). Prof. Eber Landau, the very first chief of Histology and Embryology Department at the University of Lithuania. Medicina (Kaunas) 39, 919-924.

16. Vitkus Aleksandras, Vitkus Albertas, Baltrušaitis K., Lubytė J., Masevičius J. (1983). Kauno medicinos instituto Histologijos, citologijos ir embriologijos katedrai - 60 metur [The sixtieth anniversary of the Department of Histology, Cytology and Embryology of the Institute of Medicine of Kaunas] Kaunas, p. 36. [In Lithuanian.]

\section{Address for correspondance:}

Prof. Andres Arend

Department of Anatomy, University of Tartu

Biomedicum, Ravila 19

Tartu 50411; Estonia

Tel. +3727374251

FAX: +3727374252

E-mail: andres.arend@ut.ee 